\title{
The Education Model for Authorized, Outdoor and Terrible Areas Concerning the Diversity of Environmental, Social and Culltural Conditions (Based on Local Wisdom)
}

\section{Agus Dudung1, Uswatun Hasanah², and Mirdat Silitonga ${ }^{2}$}

${ }^{1}$ Vocational Education Program, Mechanical Engineering Studies Program, State University of Jakarta, Jakarta, Indonesia

${ }^{2}$ Vocational Education Program, Family Welfare Studies Program, State University of Jakarta, Jakarta, Indonesia

\section{Abstract}

The purpose of this study is to design a model of education that is suitable for the foremost, outlying and underdeveloped areas. Research approach used was the research and development with Borg and Gall model (2003). The method used in this

Corresponding Author:

Agus Dudung

agusdudung@unj.ac.id

Received: 11 January 2019

Accepted: 14 February 2019

Published: 25 March 2019

Publishing services provided by Knowledge E

(c) Agus Dudung et al. This article is distributed under the terms of the Creative Commons Attribution License, which permits unrestricted use and redistribution provided that the original author and source are credited.

Selection and Peer-review under the responsibility of the 3rd ICTVET 2018 Conference Committee. research is descriptive research method using Focus Group Discussion approach with resource persons from various circles ranging from Education Office, Headmaster and Teacher, lecturer of University, cultural public figure, and parents, amounting to 29 people. The location of the research was conducted at schools in three districts of East Lombok-West Nusa Tenggara, Manggari-East Nusa Tenggara, and Hulu Sungai UtaraSouth Kalimantan. The Respondents in this study are education offices, principals, teachers, community leaders in three districts in Indonesia. The results show that the model of education in an authorized, outdoor, and terrible areas with local wisdom that prioritizes local wisdom will be effective by using the principles of "ASICT" (Assimilated, Supporting, Innovative, Comprehensive, and Technological Used) that will be able to accelerate and improve the achievement of the quality of education and is expected to be an alternative model in the implementation of education in lagging regions.

Keywords: development approach model, local wisdom, model of education, underdeveloped areas

\section{Introduction}

The Unitary State of the Republic of Indonesia (NKRI) with a large and heterogeneous area, geographically and sociocultural, requires appropriate efforts to overcome various problems, including education problems in the area of 3T (authorized, outdoor, and terrible). These problems are among others related to educators, such as shortage of teachers, unbalanced distribution of teachers, under qualification, low competencies, 
and inconsistencies between educational qualifications and mismatched areas, low school enrollment rates, inadequate infrastructure and inadequate access to education. The $3 \mathrm{~T}$ area requires efforts to improve the quality of education that is managed in a special and serious way to overcome the problems of education mentioned above, so that the $3 T$ areas with the development of education model for the authorized, outdoor, and terrible areas which accommodate the diversity of environmental conditions, social and cultural rights, at elementary school (SD), junior high school (SMA) and high school (SMA) this can advance together parallel to other areas. This should be the attention of the Government especially the Ministry of Education and Culture, through this research, it is necessary to implement this very urgency, considering the $3 T$ area has a strategic role in strengthening national security and the integrity of NKRI.

Based on the results of preliminary studies conducted [1] local wisdom of each region, in general, has been developed in school learning. Some of the ways that have been done are (1) by introducing and involving students in activities related to local culture, (2) scheduling local content subjects and then assigning teachers who are ready to teach the subjects; (3) giving examples to students and ordering (5) students make traditional food and explained by the teacher, (6) make the media images on the students, (7) invite students to follow the activities related to the culture area. Observations and observations have been made in several schools in $3 T$ areas, the development of local wisdom in schools has not been included in the vision and mission of the school so that the application has not been comprehensive for every subject. This has led to scientific learning based on local wisdom cannot be implemented simultaneously.

In the local wisdom-based learning applied has not had a specific theme for local wisdom-based learning. For cultural arts and learning materials based on local wisdom depends on existing learning materials. Still, the cultivation of the existing learning in the curriculum creates creative teachers in searching for themes that can be developed. Extracurricular activities in schools have been conducted and this activity is a container for raising local wisdom. In general, teachers raise local wisdom in learning through extra-curricular activities such as dancing, singing, giving skills such as weaving and so forth. The implementation is not as continuous as the core lesson because the extracurricular activities only as a supporter. The relevant activities in raising local wisdom are scouting activities, workshops, and arts.

Concerning cooperation in schools 3T The importance of cooperation between communities and schools in developing schools based on local wisdom because schools do not stand alone but are in the community. Therefore should the community and school should synergize. Schools apply local wisdom-based learning in specific subjects such 
as cultural arts and workshops with community involvement in learning. This is done for schools that do not have human resources that master the local customs and culture, especially for immigrant teachers. In general, schools get full support from the community because the community does want the learning that their children can use to help parents in everyday life. Cooperation is still limited between schools and communities. It would be better if the cooperation is further expanded with other related parties, such as the plantation companies that exist in the region help develop schools based on local wisdom.

\subsection{Provincial Education Program of 3T (Authorized, Outdoor, and Terrible) Areas}

One of the policies of the Ministry of Education and Culture, in order to accelerate the development of education in the $3 \mathrm{~T}$ area is the Indonesian Progress Movement Program (MBMI). The program includes (1) Integrated Teacher Professional Education Program and Additional Authority (PPGT), (2) Educational Undergraduate Program in 3T (SM-3T), and (3) Collaborative Teacher Professional Program (PPG Kolaboratif). These programs are part of the answer to address various education issues in $3 T$ areas. The SM-3T program as one of the MBMI Programs is aimed at undergraduates who have not served as teachers, both as civil servants (PNS) and foundation teachers (GTY), to be assigned for a year in $3 \mathrm{~T}$ area. SM-3T program is intended to help overcome the shortage of teachers, as well as preparing professional candidates who are strong, independent, and have a caring attitude toward others, and have the soul of educators to educate the nation's children, to be able to move forward to achieve the lofty ideals as mandated by the founders of the Indonesian nation.

The SM-3T Program is a Bachelor of Education Service Program to participate in addressing educational issues, accelerating educational development in $3 \mathrm{~T}$ areas and preparing professional educators for one year.

\subsection{Research questions}

1. What educational model is appropriate to accommodate the implementation of education for the foremost, outlying and underdeveloped areas based on the diversity of local environmental, social and cultural conditions (based on local wisdom)? 
2. What conceptual model of learning can improve children's interest in learning about local culture?

\section{Method}

The location of the research was conducted at schools in 3 districts of East Lombok, West Nusa Tenggara, Manggari NTT and Hulu Sungai Utara South Kalimantan. Research approach used to research and development $(\mathrm{RnD})$ with Borg and Gall model [2]. The method used in this research is descriptive research method using Focus Group Discussion approach with resource persons from various circles ranging from Education Office, Headmaster and Teacher, lecturer of University, cultural public figure, and parents, amounting to 29 people. The results of this study are used as a consideration for developing a model of Local Wisdom-Based Education in Primary, and Secondary Schools. for the foremost, outermost, and degraded areas (D3T), in accordance with existing conditions, and the establishment of test sites for the development of the approach model.

\section{Results}

Based on the results of data analysis and also FGD conducted in the area, in get the learning model that can be implemented for learning in $3 T$ area, while the model proposed based on the findings of research is the model of education for the $3 \mathrm{~T}$ area that accommodates the diversity of local social and cultural conditions Based on social wisdom) that emphasizes the principle of "ASICT" (Assimilated and Accommodated, Supporting of, Innovative Thinking, Comprehensive and Technological Used).

\section{Discussion}

This model is basically the development of the same educational model as the previous implementation, but rather put forward the principles of "ASICT". This principle emerged based on test results and also data obtained during the discussion process and also FGD during the research process. With the discovery of this principle, it is expected that the learning and teaching process implemented in $3 \mathrm{~T}$ area can take place optimally. 


\subsection{Principles of assimilation and accommodations}

Piaget [3], argues that knowledge is built through two processes, namely assimilation and accommodation. The following will be explained each process.

\section{Assimilation}

Assimilation is the process by which children evaluate and try to understand new information, based on the knowledge of the world they already have [3]. Furthermore, according to Desmita [4], assimilation is a change of external objects into internal knowledge structures. This assimilation process is based on the fact that every human moment always assimilates the information that reaches it, wherein then the information is grouped into terms that they already know. Thus, it can be concluded that assimilation is a process by which the individual integrates new perceptions, concepts or experiences into his cognitive scheme.

\section{Accommodation}

Accommodation is a process by which children expand and modify their mental representations of the world based on new experiences. While Hergenhahn [5] reveals that accommodation is a progressive growth of the cognitive structure that changes the character of all subsequent learning processes. further Desmita argues that accommodation is to change the cognitive structure that has been previously owned to be tailored to the object of external stimulus.

Based on some opinions above, it can be concluded that accommodation is the cognitive process of individuals in the face of stimuli that enter into its cognitive structure. The process of accommodation can occur in two ways: changing the scheme that exists in the cognitive structure of an individual because the experience he finds is absent in the structure of individual or individual thinking can modify the existing scheme to fit the stimulus that enters the individual.

\subsection{The principle of supporting}

The Government and the Regional Government shall ensure the availability of funds for the implementation of education for every citizen aged seven to fifteen years (Article 11 paragraph 2 of Law No. 20 of 2003 National Education System). Schools and school committees or madrasahs and madrasah committees develop their education unit curriculum and syllabus based on the underlying curriculum framework and graduate competency standards under the supervision of the city education offices responsible 
for education for elementary, junior high, and vocational schools, and handling religious affairs for MI, MTs, MA and MAK. Article 17 paragraph 2 of Government Regulation Number 19 Year 2005 on National Education Standards).

In addition to supporting any harmony between stakeholders that support the learning process, because the harmony between stakeholders will be very influential in the process of education in this area 3T. The surrounding community should also care about the implementation of education and government education institutions that are around. Do not blame all the fulfillment of national standards must be met by the government, it is also felt will hamper the process of organizing education. So that the supporting principles will affect the implementation model in this $3 T$ area.

Cooperation partnerships at various levels will be very important. The importance of learners with special needs to obtain a quality education has been mentioned before, the laws and regulations underlying it at the national level have been strong and clear from the Ministry of National Education. This does not preclude the assistance of other departments, such as the social department, the labor department and the health department in providing necessary assistance to children with special needs.

Cooperation between inter-school teachers in $3 \mathrm{~T}$ areas is needed in an effort to improve children's learning. Cooperation between teachers and parents as well as parent collaboration among parents themselves will enrich all those involved and will ensure education in better and more meaningful $3 \mathrm{~T}$ areas. Cooperation with communities such as community leaders, organizations of disability, other social organizations, in various fields is urgently needed and will provide enrichment in the implementation of education in $3 \mathrm{~T}$ areas

In essence, education is a shared responsibility between school, community and government. Therefore, the coaches, and education executors in the field are expected to empower the community in the implementation of education optimally.

\subsection{Innovative teaching and learning principles}

Innovation can be outlined as a process for introducing new ideas, new things, new services and more useful new ways. Innovation means the invention interpreted as something new for a person or group of people either in the form of discovery or invention to achieve the goal or to solve a particular problem. In innovation includes discovery and invention. Another key word in the sense of innovation is new. Santoso S. Hamijoyo in Cece Wijaya [6] describes that a new word is defined as anything that is not understood, accepted or executed by the recipient of renewal, although it may not 
be new to others. However, more important than its new nature is a qualitative nature that is different from before. Qualitative means that innovation allows for reorganization or reorganization in the field of innovation.

Even in the field of curriculum Innovation is still done in order to update the information and knowledge to be conveyed to the learners. The curriculum is a set of subjects provided by an educational institution that contains lesson plans that will be provided to the participants in a period of education. The preparation of these subject devices is tailored to the circumstances and abilities of each level of education in the provision of such education.

The length of time in a curriculum is usually adjusted to the purpose and purpose of the education system implemented. The curriculum is intended to be able to direct education toward the direction and purpose intended in the overall learning activities. In the field of innovative learning methods are growing rapidly along with the development of learning style needs that are owned by students at this time. The development of methods that are expected to be applied to the $3 \mathrm{~T}$ area is the same and tend to be more innovative than in other common areas, why, because it is in the $3 T$ area there needs to be a special treatment raised by the teacher in order to run the learning process in the classroom.

Innovation in the field of facilities and infrastructure should refer to referring to the institutions main tasks and function and applicable legislation that is UUSPN NO. LaW No. 20 of 2003 and National Education Standards PP 19 of 2005 relating to minimum criteria of study space, gyms, places of worship, libraries, laboratories, workshops, playgrounds, creative and recreational spots, and other learning resources needed to support the learning process (including the training) includes the use of information and communication technologies. Each educational unit is required to have facilities that include furniture, educational equipment, educational media, books and other learning resources, consumables, and other equipment necessary to support a regular and continuous learning process in $3 \mathrm{~T}$ areas.

\subsection{Comprehensive assessment principles}

Assessments are an important component in the organization of education. Efforts to improve the quality of education can be pursued through improving the quality of learning and quality assessment. Educational assessments need to be done professionally because (a) The results of an educational assessment can be used as a basis for making decisions about students, learning process, curriculum, and education 
policy. (B) The need to build quality and meaningful education, formulation of the policy of development and improvement of education quality. Therefore the implementation educational activities needs to be periodically assessed to obtain information useful for the decision of education policy in order to improve the quality of education. Improving the quality of education is an effort to improve the quality of human resources, improve the competitiveness of society and nation, enhance personal dignity, society and nation and realize the progress, prosperity, and welfare of people and nation.

Defines assessment as a process assessment, progress and learning outcomes (outcomes). Meanwhile [7], assessment is defined as "The process of collecting data which shows the development by learning" [8]. The Task Group on Assessment and Testing (TGAT) describes assessment as all the means used to assess individual or group performance [9].

With a good evaluation system, it will encourage educators to determine a good teaching strategy so that it can motivate learners to learn better to achieve learning objectives and educational goals as mandated in the 1945 Constitution and in the Indonesian National Education System.

\subsection{Technological principle used}

Through the utilization of educational technology, we can improve the quality of learning, that is by opening wide-width to access science and the provision of quality education. Especially the application of high tech and high touch approach. The information technology system in education provides a broad, fast, effective, and efficient range of information dissemination to various parts of the world. Information technology develops in line with the development of communication theory and technology that support the practice of learning activities. Multimedia-based learning such as computer lined learning (PBK), learning line up the web (e-learning), is a form of utilization of ICT that needs to be implemented in the world of education today.

Along with the development of educational technology and its supporting infrastructure, efforts to improve the quality of education above, among others, can be done through the use of educational technology in learning activities. Educational technology is a system that can facilitate educators and learners learn more widely, more and also varied. Through the facilities provided by the system, students can learn independently, anytime and anywhere without being limited by space and time. The material they can learn is also more varied, not only in the form of word presentation but can be richer with text, visual, audio and animation. 
For that, it is appropriate for educators should be able to create humanist learning conditions, which is a fun learning condition by optimizing the role of learning technology, especially for education in $3 T$ areas. The process of organizing education in $3 T$ areas should be able to take advantage of existing technology around the school/community to avoid lagging of information and knowledge from other centers or regions. It is expected to support the learning process in the area by optimizing technology that also supports the wisdom of the area.

\subsubsection{Test model}

The model test was conducted in four areas, i.e. the location of the study was conducted at schools in 3 districts of East Lombok, West Nusa Tenggara, Manggari NTT and Hulu Sungai Utara South Kalimantan. Based on the results of experimental models with environmental themes, then get the following results:

In the Assimilated Principles, a teacher must be able to explain various aspects related to the environment. The aspect of cleanliness of the home environment in the small scope is very important to be understood by students where students are expected to always help parents clean the house and the yard. In addition to talking about the environment, a teacher associates with beauty, because the good environment cannot be separated from the beauty factor that will be obtained through reforestation. Reforestation is not only government affairs but also at home.

Existing land use for reforestation is important to create clean and cool air in addition to economic benefits.

To explain the material with the theme of the environment, teachers can also explain the importance of community mutual cooperation in a neighborhood to do reforestation, consecration work for environmental hygiene and others. The theme of the environment is a very broad theme so that the teacher can also explain the material about the livelihood of the community in the area. For the Lombok area, the teacher explained that Lombok people have livelihoods in agriculture, marine, and tourism. This will open the students' insight to develop themselves later in the work to be desirable.

The environmental theme also discusses health in a community, family, and individual. The importance of maintaining the health of individuals for students and their families such as the habit of washing hands before eating, bathing and brushing twice a day, eating nutritious food, changing clothes every day and so forth. The theme of the environment can also be associated with the social life of the local community where each region has its own uniqueness according to its customs and culture. To create 
a healthy psychological environment, every individual must have a good relationship with others because humans as social beings where each other need each other and cannot live alone.

Supporting Principles. To carry out the learning, there needs to support from various related parties. area For example in learning with environmental themes. Because teachers who are placed as teachers who provide materials do not control local wisdom in the area, it involves more qualified community leaders in the delivery of materials related to customs and cultural values. In addition to the related learning materials, of course, the availability of facilities and infrastructure required not only the responsibility of government alone but can also involve the community and other institutions. For example for agricultural practicum is how to plant rice, students can practice in the rice fields owned by citizens. In addition to the higher classes of science and technology introduction done at other institutions to discuss the computer because the school does not have a computer device.

For health materials, students are brought to the Puskesmas doctor to explain the importance of washing hands before eating and how to brush their teeth. Innovative Principles. As a teacher, the ability to be creative is necessary because in the implementation of the placement of teachers in school is not certain that the school has adequate facilities as a supporter of learning. While the material taught must be achieved learning objectives. The ability to innovate teachers is necessary in this case. It aims to attract students' interest in learning, facilitate students in understanding a lesson and help students in imagining. In the implementation of numeracy learning, teachers should not be fixated on tools not available in the school. Counting multiplication quickly can be taught by using ten fingers that each student must have. Or to calculate summation, the teacher can use the stick or pebble that exist in the environment as a tool. This method makes students easy in understanding multiplication and addition. This will be more inherent in the students' memory.

The Principle of Comprehensive Assessment. This aspect is the aspect of the assessment done to the students in the learning process. Teacher assessment is not only the end result of learning but also the learning process. In addition, the assessment also concerns the cognitive, affective and psychomotor aspects of students who have been applied. The values contained in each subject matter must be pervasive in the student. The model of learning done by the ancient parent can be applied such as repeating verses to memorized and give the meaning of the verse in the form of styles sung every time the meeting. 
Technological Principles Used. For 3T areas that are generally left behind in access and facilities and infrastructure compared to other areas in the district city. This is not to make an obstacle to learning. A teacher and school can take advantage of the technology they have. For teachers in the $3 \mathrm{~T}$ area turned out to have a fairly modern communication device. This is seen on the Mobile owned. While every school has not all have a computer device. This is not a barrier to not receiving information or in updating learning materials. In addition, information from the department and ministry will be easily accessed by teachers.

Based on the model test results obtained as follows:

1. The learning process is more interactive because the teacher can easily follow the learning done by the teacher. More concrete learning materials so that more easily understood students.

2. From the teacher side, the teacher is easier to give understanding to the students, the teacher is more to see the students as individuals who are different from each other so as not to see the students based on the final result of learning.

3. Constraints of media limitations can be overcome by teachers because teachers are more creative.

4. Teaching materials that teachers teach can follow the existing development.

5. The values that exist in the younger local community are transferred with the help of community leaders.

\section{Conclusion}

From the results of field trials and research in order to obtain models of education in 3T areas that promote local wisdom can be concluded: (1) The developed model can be used as one of the alternative models in the implementation of education in the $3 T$ Region (2) 3T areas with local wisdom that prioritize the principles of "ASICT" developed will be able to accelerate and improve the achievement of the quality of education (3) In the model of education in 3 T region with local wisdom that puts the principle of "ASICT" is the role of stakeholders according to the authority and ability of each very meaningful for improving the quality of learning (4) In the model of education in 3T region with local wisdom that put forward the principle of "ASICT", the availability of various components of education system and harmony of working relationships accelerate and improve the achievement of the quality of education. 


\section{Funding}

This work was supported by the national grant of the Ministry of Research, Technology and Higher Education.

\section{Acknowledgement}

The author would like to thank the ministry of research, technology and higher education, rector of the Jakarta State University, Head of the Jakarta State University research institute and the local education office.

\section{Conflict of Interest}

1. The model of education in $3 T$ areas with local wisdom that prioritizes the principle of "ASICT" is expected to be an alternative model in the implementation of education in the disadvantaged areas.

2. The model of education in $3 T$ areas with local wisdom that prioritizes the principle of "ASICT" needs to be tested in other areas besides sample areas in this study.

\section{References}

[1] Dudung, A, dkk (2017). Model Pembelajaran Saintifik Mata Pelajaran IPS untuk Siswa SD di daerah 3T. Jakarta: Penelitian Dikti.

[2] Gall, M. D., W. R. Borg, and J. P. Gall. (2013). Case study research. Educational research: An introduction, 123-163.

[3] Upton, Penney, and Charlotte Elizabeth Taylor. (2014). Psychology Express: Educational Psychology (Undergraduate Revision Guide): Pearson UK.

[4] Desmita. (2012). Psikologi Perkembangan Peserta Didik. Bandung: Rosda Karya.

[5] Hergenhahn, B.R. (2010). Theory Of Learning. Jakarta: Kencana Perdana Media Group.

[6] Cece, Wijaya. (1992). Kemampuan Dasar Guru Dalam Proses Belajar Mengajar. Bandung: PT Remaja Rosda Karya

[7] Stiggins, R.J.M. (1994). Student Centered Classroom Assessment. New York: McMillan College Publishing Co. 
[8] Kumano, Y. (2001). Authentic Assessment and Portfolio Assessment-lts Theory and Practice. Japan: Shizuoka University.

[9] Griffin, P., Nix., P. (1991). Educational Assessment and Reporting. Sydney: Harcout Brace Javanovich Publisher. 